\title{
O Contratualismo e seu legado nas teorias de Relações Internacionais: um olhar a partir do Brasil
}

\author{
Gills Vilar-Lopes \\ Lucas Moura Maximo \\ Theo Antônio Rodrigues Sant'Ana*
}

\begin{abstract}
Resumo
Este trabalho apresenta o pensamento contratualista da Teoria Política Moderna, com o objetivo geral de enfatizar alguns de seus reflexos nas Relações Internacionais. Metodologicamente, utiliza-se o estilo de pesquisa qualitativo, para selecionar somente obras contratualistas que impactam as teorias de Relações Internacionais. Esse recorte é feito a partir de epistemologia aplicada no Brasil. Assim, analisam-se as obras contratualistas de Baruch de Espinosa, Immanuel Kant, Jean-Jacques Rousseau, John Locke e Thomas Hobbes, com o intuito de, comparativamente, expor sua relação com as teorias internacionalistas.
\end{abstract}

Palavras-chave: Contratualismo; Teoria Política Moderna; Teoria de Relações Internacionais.

\section{Abstract}

Contrarianism and its legacy on International Relations Theory: an outlook on the Brazilian branch

This work brings on the Modern Political Theory contractarianism and aims to uncover some of the echoes it holds in the International Relations field. A qualitative inquiry method is applied to ensure only contractarianism works of sound impact over Brazil's International Relations are herein mentioned. Hence, the arch works of Baruch Spinoza, Immanuel Kant, Jean-Jacques Rousseau, John Locke and Thomas Hobbes are here in below analyzed and compared in order to unveil their linkages with International Relations Theories.

Keywords: Contractarianism; Modern Political Theory; International Relations Theory.

\footnotetext{
* Gills Vilar-Lopes é professor Adjunto do Departamento de Ciências Sociais (DCS) da Universidade Federal de Rondônia (UNIR). E-mail: gills@gills.com.br. Lucas Moura Maximo é graduando em Relações Internacionais pela Universidade Federal da Paraíba (UFPB) e membro do Grupo de Pesquisa "Política Externa, cooperação e desenvolvimento" (UFPB). E-mail: lucasmax2196@gmail.com. Theo Antônio Rodrigues Sant'Ana é graduando em Relações Internacionais pela UFPB: theo.a.rod.san@gmail.com.
} 


\section{Introdução}

O contratualismo é um movimento jusnaturalista dentro da teoria política moderna ${ }^{1}$ com bases que remontam à Grécia Antiga - especificamente à polis grega -, permeando diferentes campos do saber, tais como Ciência Política (CP) e Relações Internacionais (RI)².

A metáfora do contrato/pacto social tem, até hoje, papel significante para o entendimento de conceitos-chave para as análises políticas, tais como poder, legitimidade, governo e sociedade políticos (Hardin, 2007, p. 241). No âmbito internacional, a noção da existência de direitos, ancorados por meio de um pacto, pode ser vista também nos considerandos de tratados e nas recomendações de políticas públicas.

Diante de tal tema, indaga-se: em que medida o contratualismo influencia RI? A fim de prover uma resposta a esse problema de pesquisa, conjectura-se que tal influência - ou legado, como chamamos - reverbera, sobretudo, na epistemologia de $\mathrm{RI}$, a ponto de se constituir amiúde em condição necessária - mas não suficiente - para o mainstream das teorias internacionalistas. Nesse viés, o objetivo geral do presente trabalho visa a analisar como se dá essa influência.

De antemão, destaca-se que o conceito de contratualismo possui dois sentidos, um amplo e outro restrito. O primeiro diz respeito às várias teorias políticas que atribuem a um contrato - ou pacto - a base primária da sociedade ${ }^{3}$ e do poder político (Bobbio; Matteucci; Pasquino, 2004, p. 272)4. Já o segundo sentido refere-se a uma escola europeia de pensamento que "teve seus máximos expoentes em J. Althusius (1557-1638), T. Hobbes (1588-1679), B. Spinoza (1632-1677), S. Pufendorf (1632-1694),

\footnotetext{
${ }^{1}$ Embora os contratualistas também sejam enquadrados na subárea da teoria política "clássica", preferimos o epíteto "moderna", pois é justamente na chamada Idade Moderna - geralmente datada de 1453 a 1789 - que, de fato, tal escola de pensamento floresce e adquire lugar privilegiado na filosofia política (Bobbio; Matteucci; Pasquino, 2004, p. 272).

$2 \mathrm{O}$ termo homógrafo "Relações Internacionais" (RI) designa a área do saber cujo objeto de estudos são as "relações internacionais". Já o adjetivo "internacionalista" diz respeito a tal área; e "internacional", portanto, a seu objeto.

${ }^{3}$ Cf. Bonavides (2006, p. 61).

${ }^{4}$ Como se observa mais adiante, essa ideia-força não é unânime, a ponto de pensadores, como David Hume, advogarem que é ilógico pensar em como um amplo consenso pode ser alcançado no estado de natureza sem que já exista um regime político prévio (Hardin, 2007, p. 242).
} 
J. Locke (1632-1704), J.-J. Rousseau (1712-1778), [e] I. Kant (1724-1804)" (Bobbio; Matteucci; Pasquino, 2004, p. 272). Nesse viés, trabalha-se aqui com ambos os sentidos, diferenciando-os quando oportuno, com especial atenção ao legado que alguns dos autores supracitados deixaram para as teorias de RI.

Pelo fato de haver apenas sete expoentes, este trabalho pauta-se, metodologicamente, no estilo de pesquisa qualitativo, em que pese o uso da pesquisa bibliográfica e do método comparativo ${ }^{5}$. As fontes primárias, portanto, são as obraschave desses autores, as quais abordam especificamente a teoria do contratualismo político. Dessa forma, busca-se firmar, a priori, um panorama dos principais pressupostos e corolários contratualistas, classificando-os ${ }^{6}$ por meio de um quadroresumo, e, a posteriori, confrontá-los entre si e com o mainstream das teorias de RI.

O marco teórico ancora-se nos principais autores e pressupostos do que se conhece por mainstream de RI, qual seja, a teoria realista das relações internacionais, que surge em contraposição à liberal. Posto que essas teorias possuem vários desmembramentos e vertentes favoráveis e contrárias, focam-se em suas versões clássicas, pois é a partir delas que se desenvolvem reformulações, vertentes e correntes alternativas. Ademais, teóricos racionalistas da chamada Escola Inglesa de RI também são chamados a complementar o debate entre as duas teorias supracitadas.

O presente paper divide-se em três seções principais, a saber: a primeira diz respeito aos aspectos metodológicos por trás da pesquisa proposta; a segunda seção trata da teoria contratualista em si, explorando seus principais conceitos e adiantando possíveis indícios de seu legado; e a terceira seção principal investiga a influência contratualista nas diferentes tentativas explanatórias das relações internacionais.

\footnotetext{
${ }^{5}$ A ligação inferencial entre o estilo de pesquisa e o número de observações advém de King, Keohane e Verba (1996, passim). A escolha do tipo de pesquisa bibliográfica coaduna-se com Cervo, Bervian e Da Silva (2010, p. 60-62). Por fim, o método comparativo é uma abordagem qualitativa (Brady; Collier; Seawright, 2004, p. 4) que auxiliará alcançar, indutivamente, o objetivo geral deste trabalho. Cf. próxima seção.

${ }^{6}$ Como qualquer classificação, agrupam-se semelhanças e separam-se diferenças, que, neste caso, estão ligadas pelo tema "legado contratualista em RI".
} 


\section{Aspectos metodológicos}

A presente seção visa a apontar quais motivos e obras serão analisados com base no objetivo geral. Assim, a pesquisa bibliográfica busca filtrar os pensadores e suas obras contratualistas que possuem impacto em RI.

Deve-se ter em mente que o sentido estrito de contratualismo baseia-se nos sete autores já arrolados na seção anterior. Logo, destacam-se suas seguintes obras que trazem as teorias originais sobre o contrato social:

1. Politica methodice digesta atque exemplis sacris et profanis illustrata (1603), de Johannes Althusius;

2. Leviatã (1651), de Thomas Hobbes;

3. Tratado teológico-político (1677), de Baruch de Espinosa7;

4. Os deveres do homem e do cidadão (1682), de Samuel von Pufendorf;

5. Segundo tratado sobre o governo civil (1689), de John Locke ${ }^{8}$;

6. Do contrato social (1762), de Jean-Jacques Rousseau; e

7. A paz perpétua (1795), de Immanuel Kant.

Como tentativa de mensurar a influência ou o impacto em RI dos autores e obras elencadas supra, realiza-se uma pesquisa em planos de aulas de disciplinas teóricas ofertadas pelos principais programas de pós-graduação (PPGs) brasileiros em $\mathrm{CP}$ e $\mathrm{RI}^{9}$.

Como critério de seleção, escolhem-se aqueles programas que possuem conceitos 6 e 7 da Área de Avaliação "Ciência Política e Relações Internacionais" da CAPES. Assim, apenas seis PPGs credenciam-se, quais sejam: os de CP da Universidade de São Paulo (USP), da Universidade Federal de Minas Gerais (UFMG), da Universidade

\footnotetext{
${ }^{7}$ Sobre Espinosa, vale salientar que seus construtos conceituais partem de uma adequação ao raciocínio, à concepção ontológica de Deus e à existência humana com suas condições existenciais, expressas sobretudo nos primeiros 15 capítulos do Tratado Teológico-Político (1670). Uma análise abrangendo toda essa progressão mereceria, decerto, um trabalho à parte; aqui, expõem-se apenas as frações adequadas ao contratualismo, mormente apontadas na parte política de seu tratado.

8 O Primeiro Tratado (1681) é uma crítica à obra O Patriarca (1680), de Robert Filmer; já o Segundo Tratado, também de 1681, é um "ensaio sobre a origem, os limites e os fins verdadeiros do governo civil" (Locke, 2006, p. 35).

${ }^{9}$ A pesquisa é realizada nos PPGs em CP e RI porque, no âmbito da Coordenação de Aperfeiçoamento de Pessoal de Nível Superior (CAPES), ambos os campos fazem parte de uma só Área de Avaliação. O estudo se baseia no caso brasileiro, por questões logísticas para se pesquisar cada um dos planos de aula.
} 
Estadual do Rio de Janeiro (UERJ) e da Universidade Federal de Pernambuco (UFPE); e os de RI da Pontifícia Universidade Católica do Rio de Janeiro (PUC-Rio) e da Universidade de Brasília (UnB $)^{10}$.

A Tabela 1 apresenta os achados da pesquisa, levando em conta tanto o sentido estrito de contratualismo quanto os critérios de seleção para a amostra da pesquisa.

Tabela 1 - Obras contratualistas nos planos de aulas de PPGs em CP e RI com CAPES 6-7

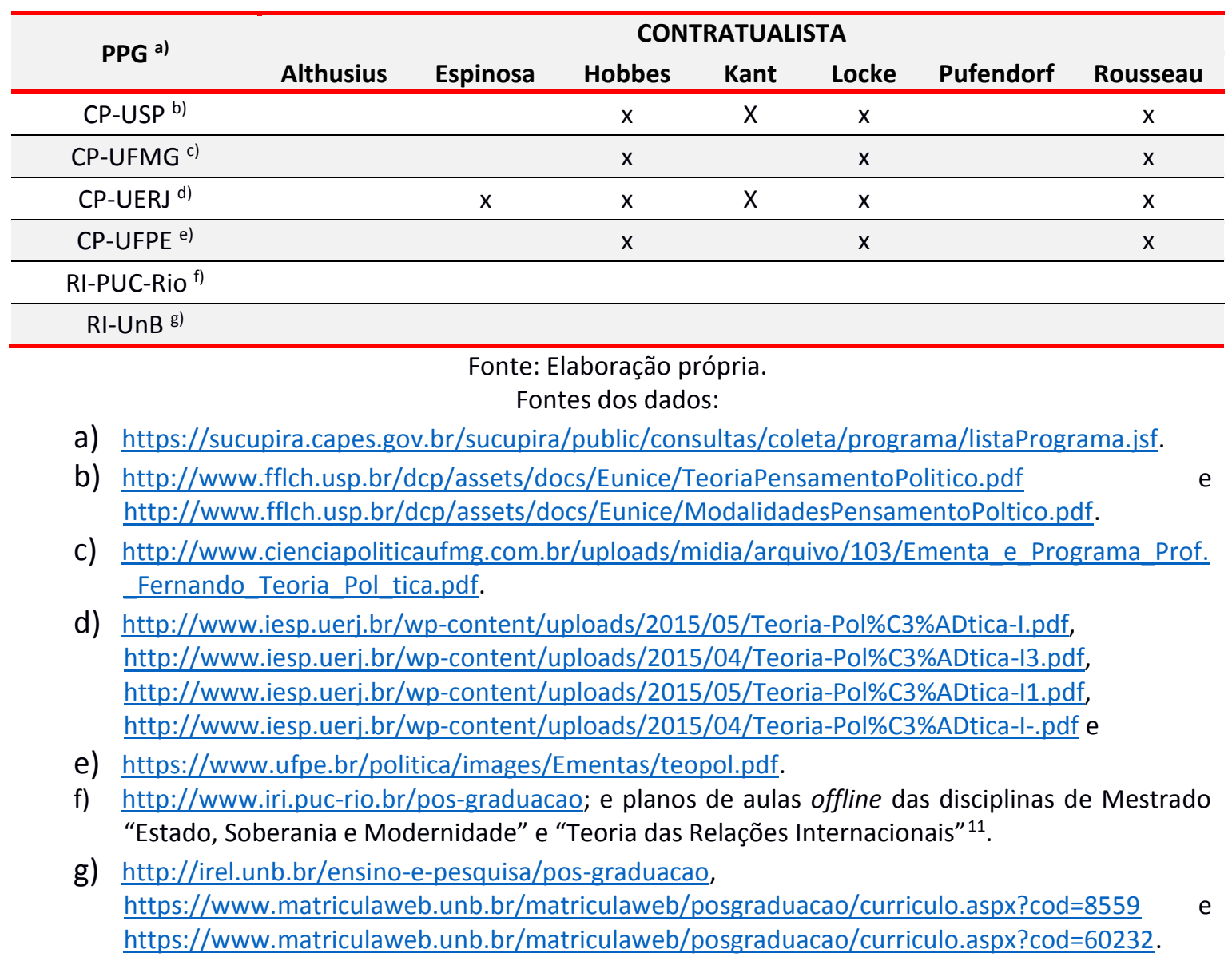

Como se vê na Tabela 1 , tanto Althusius quanto Pufendorf ${ }^{12}$ são os únicos autores que não são utilizados por quaisquer dos PPGs da amostra. Esse achado coaduna-se com Boisen e Boucher (2010), que atentam para a necessidade de suprir a lacuna existente entre a teoria política e as teorias de RI, evidenciando como os escritos de Grotius, Vattel e Pudendorf são, por exemplo, pouco explorados academicamente.

Outro vazio que chama atenção está no fato de os dois únicos PPGs stricto sensu

\footnotetext{
${ }^{10}$ Esta listagem foi elaborada levando em conta a avaliação da CAPES de 2015.

${ }^{11}$ Os autores agradecem à Me. Ludmilla de Gois, pela disponibilização dos arquivos.

12 Para uma breve análise comparativa entre Pufendorf e Hobbes, vide Boisen e Boucher (2010).
} 
em RI da amostra - PUC-Rio e UnB - também não utilizarem sequer um contratualista. Entretanto, vale ressaltar que PPGs em CP, como os da UERJ e da UFPE, possuem linhas de pesquisa em Política Internacional e RI, respectivamente, sendo aquele o único PPG da amostra a lecionar Espinosa. Além disso, Hobbes, Locke e Rousseau são, de longe, os contratualistas que mais figuram nos planos de aulas averiguados. Ao final do texto, será possível atestar se esses primeiros achados da pesquisa coadunam-se, de fato, com a conclusão da análise.

Como reflexo direto da Tabela 1, justifica-se que as obras a serem analisadas aqui são aquelas cujos autores aparecem apenas nos resultados da pesquisa, ou seja, as de Espinosa, Hobbes, Kant, Locke e Rousseau, diminuindo, assim, de sete para cinco autores que podem ter deixado um legado contratualista para RI, conforme a próxima seção busca revelar.

\section{O legado contratualista}

Os contratualistas defendem que a gênese da sociedade e do poder político advém de um contrato ou pacto social, i.e., de "um acordo tácito ou expresso entre a maioria dos indivíduos, acordo que assinalaria o fim do estado natural e o início do estado social e político" (Bobbio; Matteucci; Pasquino, 2004, p. 272). Diante de definições amplas como essa, deve-se atentar ao agrupar teóricos políticos tão distintos e de épocas e locais tão diferentes, como se tivessem orientações plenamente convergentes entre si. Afinal, ao versar sobre a "escola contratualista", está, na realidade, tratando-se de uma mesma terminologia para denotar a racionalização da força e o sustentáculo do poder no consenso, elementos que, por excelência, também perpassam não apenas a ordem interna de uma sociedade, mas também suas relações exteriores.

Analisando escritos contratualistas, é possível notar uma matriz que estrutura o processo de engendramento do Estado. Dito de outra forma, vê-se, na produção dos cinco autores aqui selecionados, a defesa de um método a que epitetamos de "pseudotripartite" para o nascimento do que se conhece atualmente como Estado Moderno, baseado nos seguintes estados/estágios/etapas/fases/momentos: 
(i) estado de natureza: geralmente contrário àquilo que é artificial e socialmente criado pela (re)união dos indivíduos;

(ii) contrato/pacto social: mediante o qual os indivíduos concedem e transmitem o poder político entre $\mathrm{si}^{13}$; e

(iii) estado civil/social/político: que faz surgir automaticamente ${ }^{14}$ um estado de coisas mais organizado e hierarquizado, conhecido por "o estado" ou, simplesmente, Estado.

A Figura 1 apresenta a engenharia por trás da ideia-chave do contratualismo.

Figura 1 - Esquema pseudotripartite do contratualismo político

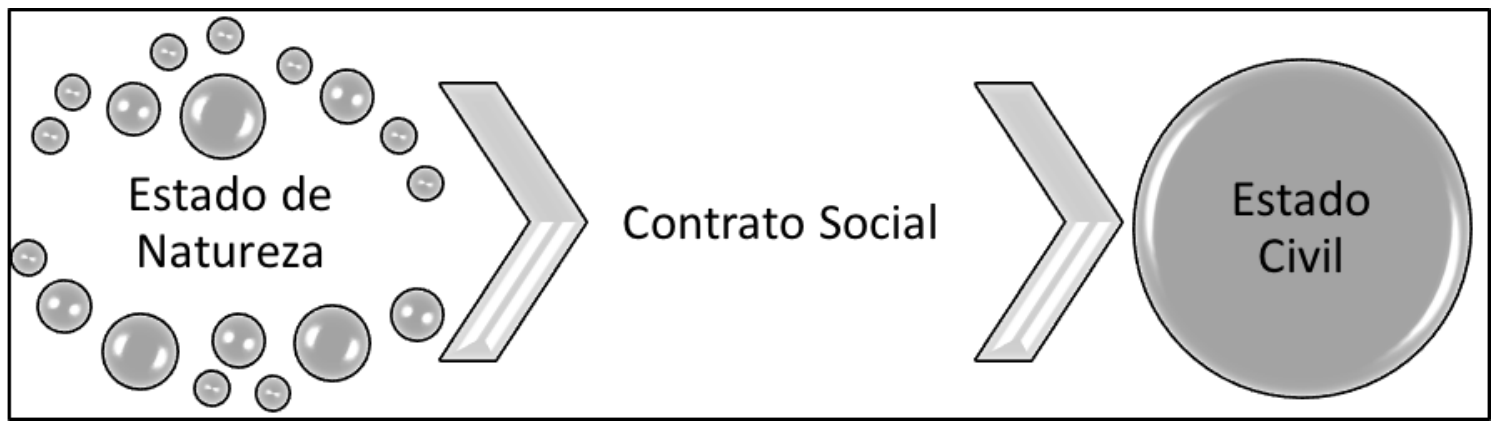

Fonte: Elaboração própria.

De toda sorte, a mecânica proposta pelos contratualistas não é tão simplória quanto a Figura 1 demonstra. Por exemplo, caracterizar o estado de natureza como um estado prévio ao estado civil e do qual o indivíduo busca livrar-se, por intermédio de um contrato social, constitui um desafio ontológico assaz complexo. Não obstante, cada um dos contratualistas detém sua própria ideia de tais momentos, gerando, logicamente, divergências e convergências entre si. As próximas duas subseções visam a analisar e comparar essas visões, a fim de que se possa obter o substrato conceitual que tanto caracteriza o mainstream das teorias de RI.

\subsection{Do Estado de Natureza}

Este é o estágio prévio à inserção do indivíduo em uma estrutura sociopolítica e

\footnotetext{
${ }^{13}$ Castan (1991, p. 27) chama, ironicamente, isso de "servidão voluntária", ou seja, "a mais incrível das perversões do vínculo social [...] que instituía a tirania de um sobre todos".

${ }^{14}$ Ora, se o estado civil surge automaticamente com o firmamento do contrato social, então não são três estados ou etapas, mas sim duas, sendo o contrato social apenas uma zona cinzenta. Daí nossa inquietação contida na palavra "pseudotripartite".
} 
com instituições artificiais. Dado que, aqui, a subjetivação da natureza humana parte do nível individual para o coletivo, destacam-se as seguintes variáveis explicativas do estado de natureza: liberdade, propriedade, natureza humana e estado de guerra. Como será visto na quarta seção, infra, esses elementos estão relacionados à busca e à manutenção do poder não apenas na ordem interna dos Estados, mas igualmente na internacional, tendo, portanto, maior relevância para as teorias de RI.

Acerca da liberdade, Hobbes (2005) entende que o estado de natureza corresponde ao estágio em que os indivíduos vivem desorganizadamente em uma verdadeira anarquia, onde a liberdade individual é total, haja vista que todos fazem o que Ihes aprouver, inexistindo, assim, segurança. Para Locke (2006, p. 36), o estado de natureza aloca os grupos de pessoas em uma espécie de progressão evolutiva em que eles vivem livres e iguais, dentro dos limites do direito natural, sem que essa liberdade implique uma similar permissividade, de modo que "um homem adquire um poder sobre o outro; mas não um poder absoluto ou arbitrário" (Locke, 2006, p. 37). Apesar de Locke aludir à razoabilidade dos indivíduos no estado de natureza, Espinosa (2008) aponta que a razão só pode manter a ordem no estado civil, e não no natural, assemelhando-se aqui a Hobbes, porquanto, tudo sendo lícito a todos (Espinosa, 2008, p. 13, 238), os indivíduos realmente não podem nada, pois são oprimidos pelas capacidades - conatus - de todos os demais ${ }^{15}$. Rousseau (2002), por seu turno, apregoa que a liberdade só é possível no estado de natureza. As teorias de RI enfocarão essas limitações da liberdade que os Estados têm de agir irrestritamente no plano internacional, sobretudo no que concerne às críticas e justificativas das chamadas guerras santas e preventivas.

Sobre a propriedade, Hobbes (2005, p. 100) apregoa que o estado de natureza não propicia seu legítimo estabelecimento, uma vez que, "se não for instituído um poder suficientemente grande para a nossa segurança, cada um confiará [...] apenas na sua própria força e capacidade". Semelhantemente ao pensador inglês, Rousseau (2003) aponta que, nesse aspecto, a propriedade só pode ser assegurada pela força.

\footnotetext{
${ }^{15}$ Segundo Espinosa (2008, p. 241), liberdade é a característica de se deixar conduzir, sem reservas e unicamente, pela razão; conatus, por sua vez, é a potência contida no fato de "que cada indivíduo tem pleno direito a tudo o que está em seu poder" (Espinosa, 2008, p. 234). Como lembra Chauí (1995, p. 73), conatus, na política, chama-se direito natural e é preservado ao longo do estado civil.
} 
Por sua vez, Locke compreende a propriedade ora como "a vida, os bens e a liberdade como direitos naturais" (Mello, 1999, p. 85), ora como a posse de bens móveis ou imóveis. Utilizando este último conceito - mais estrito - de propriedade, Kant (2008, p. 9) afirma que certos tipos de posse são proibidos tanto no estado de natureza quanto no civil, pois no primeiro inexistem leis externas ao indivíduo (Kant, 2008, p. 10, 15) ou seja, um indivíduo não pode legislar sobre outro.

Um dos elementos mais notórios nas teorias de RI é a discussão de como a natureza humana dos tomadores de decisão influencia as ações externas dos Estados. No mainstream internacionalista, esse debate é, geralmente, posto entre defensores e opositores de Hobbes e Maquiavel, ou seja, do realismo político. De acordo com Hobbes (2005), devido à inerente falta de transparência, os indivíduos se esforçam, constante e mutuamente, para supor qual será a atitude mais razoável e plausível de seus semelhantes, lançando, assim, as bases para o dilema de segurança, uma das mais utilizadas teses dos Estudos de Segurança Internacional, como se vê na quarta seção. Com uma visão diferente da de Hobbes, Locke (2008, p. 39) afirma que a natureza humana não é belicosa. Rousseau (2003, p. 115) - mais preocupado em demonstrar como o Estado vive, e não como ele age - afirma que o puro estado de natureza é estranho à condição humana e que ele só é superado quando o indivíduo reconhece seu semelhante como tal. Aqui, a variável razão é novamente exposta, fazendo com que Rousseau e Espinosa se coadunem sobre sua importância no estado civil. Espinosa, por seu turno, diverge de outros contratualistas aqui abordados, ao afirmar que o homem não é dotado do interesse de sobrevivência e autoconservação, mas que ele sim é a própria força de autoconservação denominada conatus (Aurélio, 2008, p. 363). Nem tão pessimista quanto Hobbes nem tão otimista como Locke, a concepção de Espinosa (2008, p. 6-7) sobre a natureza humana se assemelha mais à de Rousseau, exemplificando que a base amoral do comportamento humano pode ser medida no fato de que, quando amedrontado, o homem busca a superstição, que é a grande fomentadora das guerras (Espinosa, 2008, p. 311).

O estado de guerra é outro tema bastante em voga nas teorias internacionalistas. Sobre ele, Hobbes (2005, p. 102) afirma que os homens competem por honra e dignidade e que a mútua semelhança entre eles faz com que se ataquem ou sempre estejam preparados para tanto -, até mesmo preventivamente. Tal padrão anárquico, que caracteriza o estado de guerra e constrange a todos, leva os indivíduos 
a se apresentarem em uma constante competição, em que seu objetivo primordial é a manutenção de suas próprias vidas. Kant $(2008$, p. 10) é outro contratualista que concorda que o estado de natureza equivale a um estado de guerra, visto que, nele, há a ameaça constante das hostilidades. Contrariamente a Hobbes e Kant, Locke (2006, p. 39-40) distingue o estado de natureza do de guerra, pois o primeiro é, de acordo com ele, um estágio relativamente pacífico. Apontando o homem como sendo capaz de cooperar mutuamente, Rousseau (2003, p. 120) - avesso às ideias de Hobbes, assim como o faz Locke - entende que o estado de guerra entre os indivíduos provém justamente de suas paixões e vícios, mas não o contrário. Novamente, a quarta seção aborda a visão caricaturesca do estado de natureza como uma condição de guerra de todos contra todos, que leva, séculos depois, o mainstream teórico de RI a amarrar tal estado de coisas ao contexto político internacional do entreguerras do século XX. Por seu turno, as perspectivas rousseauniana e lockiana servirão de base para a teoria liberal confrontar os realistas de conotação hobbesiana.

Após esses aspectos-chave do estado de natureza serem revelados, busca-se a seguir apresentar os pressupostos do momento mais crítico da teoria contratualista: a passagem do estado de natureza para o estado civil, por meio de um pacto.

\subsection{Do Contrato Social e do Estado Civil}

A depender do autor, as terminologias estado civil/político/jurídico/coletivo/soberano ou, simplesmente, Estado consignam o estágio vivenciado por indivíduos em uma estrutura sociopolítica ordenada. O contratualismo toma esse estado geralmente como uma negação ao estado de natureza, graças principalmente a um contrato ou pacto social. Ao analisar essa passagem, alguns contratualistas criam verdadeiros corolários tanto para as teorias políticas quanto para as internacionalistas. Por exemplo, temas como solução de conflitos, imbróglio fronteiriço, intervenção e autodeterminação podem ser analisados, respectivamente, à luz de conceitos pós-estado de natureza, como estado de guerra, propriedade (pública x privada), liberdade (submissão x consentimento) e formas de Estado e governo, os quais só são possíveis em Estados civis - mesmos nos ditos "falidos". Nesse sentido, a 
presente subseção busca identificar e compreender tais conceitos contratualistas.

Como visto, Hobbes (2005) afirma que os indivíduos, no estado de guerra, abdicam de suas liberdades individuais e renunciam seus direitos naturais, buscando sair dessa anarquia decadente. Além do fundamento jurídico centrado no contrato social, os homens concordam em se submeter a um só homem (Hobbes, 2005, p. 103), devendo existir também um Estado dotado de força suficiente para compelir os súditos $^{16}$. Assim, o surgimento do Estado está consubstanciado na famosa metáfora do Leviatã, um deus mortal, definido por Hobbes (2005, p. 103, grifo nosso) como "[u]ma pessoa de cujos atos uma grande multidão, através de acordos mútuos uns com os outros, foi instituída". Os motivos hobbesianos para acabar com o estado de guerra, por meio da transição do estado de natureza para o civil, encontra certa semelhança em Kant (2008, p. 10), Locke (2006, p. 58) e Rousseau (2003, p. 136).

Ademais, o contrato social lockiano recorre não apenas ao estado de guerra, como também à propriedade, pois garantiria os direitos inalienáveis à vida e aos bens em geral (Locke, 2006, p. 58). Porém, a guerra, com o firmamento do contrato, passa a ter caráter público, e não mais individual ou privado (Rousseau, 2003, p. 136), um importante legado para a compreensão das reais competências do Estado - por exemplo, postas na teoria weberiana - ou das chamadas instituições efetivas da ordem internacional a que os racionalistas Bull (2002) e Wight (2002) se referem. Ainda sobre a propriedade, Hobbes afirma que, no estado civil, ela somente pode existir, ser garantida ou dividida sob o poder e os fundamentos do soberano. Não concordando com isso, Locke (2006) alicerça a propriedade como um direito superior e anterior ao Estado, ostentando, assim, sua filosofia individualista. Já para Rousseau (2003), o Estado deixa de assegurar a propriedade pela força, e, caso seja pretérita ao contrato, deve ser garantida, e, se ulterior, gerida pelo soberano.

Os contratualistas também buscam encontrar o grau de liberdade em que se firma um contrato social. Mais adiante, ver-se-á como a problemática da falta de um legislador mundial constrange ou não as relações entre os Estados, a partir dessa perspectiva. Por ora, aponta-se que, de um lado, Hobbes concebe o contrato como um pacto de submissão em que os homens abrem totalmente mão de sua liberdade natural, transferindo-a para o soberano, com vistas a garantir sua sobrevivência; e, do

\footnotetext{
16 Para Espinosa (2008, p. 241-242), “súdito" é aquele que faz parte de uma sociedade pautada pela razão e que segue ordens estatais úteis ao bem comum.
} 
outro, Locke (2006, p. 39) pondera que o abandono contratual do estado de natureza é um pacto de consentimento, uma convenção, "em que os homens concordam livremente em formar a sociedade civil para preservar ainda mais os direitos que possuíam originalmente no estado de natureza" (Mello, 1999, p. 86). Como se vê, o contrato lockiano é um consentimento, mas, para Hobbes (2005, cap. XVII), “[...] é mais do que consentimento, ou concórdia, é uma verdadeira unidade de todos eles, numa só [...] pessoa". Ao contrário dessa visão hobbesiana, Espinosa (2008, p. 239-240) apregoa que a passagem do estado de natureza para o civil não se perfaz pela simples reunião dos direitos naturais dos pactuantes, mas, sim, por sua união, o chamado conatus político. Nessa lógica, Rousseau (2003, p. 125) pondera que a igualdade é legitimada pelo direito, que passa a moralizar os súditos, tornando a vontade pública um fim em si mesmo e, assim, o ato de soberania será sempre justo, pois provém do contrato social. Dessa forma, o estado civil rousseauniano garante a liberdade de todos os indivíduos por meio da cooperação. Destaca-se que praticamente todas as teorias de RI transbordam a questão da cooperação para a via internacional; algumas inclinam-se mais para a vertente hobbesiana; outras, rousseauniana, indagando se os ganhos com ela serão absolutos ou relativos para quem coopera.

Quando o direito natural coletivo torna-se civil, ele concomitantemente gera o estado civil - conatus coletivo ou o soberano -, e transforma a multidão no próprio sujeito político que afirma o desejo de governar e não ser governado. Ao surgir um novo estado, faz-se mister definir seus contornos e essência. Nesse sentido, Hobbes (2005, p. 109) prefere a monarquia absolutista - como a própria capa de sua obra-mor já aponta -, construindo uma noção de soberania sobre bases morais. Por seu turno, Locke defende o parlamentarismo, a propriedade privada e os direitos civis, individuais e políticos. Entrementes, tais predisposições são mais bem compreendidas pelo contexto histórico em que esses autores seiscentistas estão inseridos. A título de exemplo, a Inglaterra de Locke passa por conflitos entre a Coroa e o Parlamento burguês. O liberalismo político só vai triunfar sobre o absolutismo no final da década de 1680, especialmente com a assinatura do Bill of Rights, em 1689, tornando a Inglaterra uma monarquia limitada pelos amplos poderes do parlamento (Mello, 1999, p. 82-83). Nesse viés, a passagem para o governo civil ocorre quando "não é [mais] razoável que 
os homens sejam juízes em causa própria" (Locke, 2006, p. 38). Frente a isso, Espinosa $(2008$, p. 239, 242) afirma que o regime político mais apto a realizar esse desejo a que Locke alude é a democracia, pois os demais são distorções do conatus que possibilitam relações de dominação, e que, por isso, é na forma de governo republicana, e não na monárquica, que a liberdade pode perdurar (Espinosa, 2008, p. 8).

Como se observa até aqui, os contratualistas possuem visões próprias sobre os elementos necessários e suficientes para o rito de passagem para o estado civil. 0 Quadro I apresenta as nuances dessas visões, de modo que, a partir delas, será possível encontrar, na próxima seção, os principais matizes em torno do mainstream internacionalista.

\section{Quadro 1-O legado contratualista}

\begin{tabular}{|c|c|c|c|}
\hline Autor & Estado de Natureza & Contrato Social & Estado Civil \\
\hline Hobbes & $\begin{array}{c}\text { - absoluta liberdade } \\
\text { individual } \\
\text { - estado de guerra de } \\
\text { todos contra todos } \\
\text { - anarquia (ausência de } \\
\text { governo) } \\
\text { - indivíduo tem direito } \\
\text { de punir o crime }\end{array}$ & $\begin{array}{l}\text { - supera o ato do } \\
\text { consentimento } \\
\text { - pacto de submissão } \\
\text { em que indivíduos } \\
\text { abrem mão de sua } \\
\text { liberdade fundamental }\end{array}$ & $\begin{array}{l}\text { - concretização da } \\
\text { metáfora do Leviatã } \\
\text { - um só soberano para } \\
\text { todos os súditos } \\
\text { governar e administrar } \\
\text { seus bens }\end{array}$ \\
\hline Kant & - estado de guerra & $\begin{array}{c}\text { - gerado pela liberdade, } \\
\text { igualdade e } \\
\text { dependência jurídica de } \\
\text { todos os súditos por } \\
\text { meio de uma } \\
\text { Constituição } \\
\text { republicana }\end{array}$ & $\begin{array}{c}\text { - estado de paz } \\
\text { - prevalência do Direito } \\
\text { - necessidade de uma } \\
\text { "federação } \\
\text { internacional" }\end{array}$ \\
\hline Locke & $\begin{array}{c}\text { - absolutas liberdade e } \\
\text { igualdade } \\
\text { - relativa paz e harmonia } \\
\text { - não exclui o estado de } \\
\text { guerra } \\
\text { - indivíduo tem direito } \\
\text { de obter a reparação }\end{array}$ & $\begin{array}{l}\text { - convenção que cria } \\
\text { uma comunidade e um } \\
\text { corpo político } \\
\text { - garantia dos direitos } \\
\text { inalienáveis (vida, } \\
\text { propriedade e bens) } \\
\text { - pacto consensual para } \\
\text { preservar os direitos }\end{array}$ & $\begin{array}{l}\text { - solução adequada para } \\
\text { as inconveniências do } \\
\text { estado de natureza } \\
\text { - contenção da } \\
\text { parcialidade e da } \\
\text { violência dos homens }\end{array}$ \\
\hline Rousseau & $\begin{array}{c}\text { - estado de instabilidade } \\
\text { perene } \\
\text { - liberdade só pode } \\
\text { existir aqui } \\
\text { - perfeita independência } \\
\text { - propriedade } \\
\text { assegurada pela força } \\
\text { - desordem vs. caos }\end{array}$ & $\begin{array}{c}\text { - estabelecimento de } \\
\text { valores, punições e } \\
\text { justiça social } \\
\text { - criação de instituições } \\
\text { políticas, novos } \\
\text { sentimentos e soberania } \\
\text { - concretização da busca } \\
\text { pela felicidade } \\
\text { - geração da ordem } \\
\text { social }\end{array}$ & $\begin{array}{l}\text { - asseguração da } \\
\text { propriedade pré- } \\
\text { contrato } \\
\text { - gerenciamento da } \\
\text { propriedade pós- } \\
\text { contrato } \\
\text { - garantia da liberdade } \\
\text { de todos por meio da } \\
\text { cooperação }\end{array}$ \\
\hline
\end{tabular}


- restringe a liberdade

- cada indivíduo faz suas

Espinosa próprias leis, levando à diminuição do conatus e

à guerra generalizada

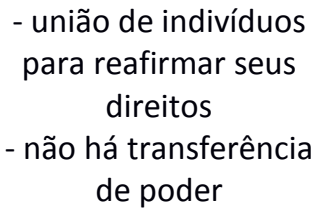

- promoção da paz e da segurança

- concretização do

estado de natureza

- conatus coletivo

- prevalência da razão

sobre a superstição

Fonte: Elaboração própria.

\section{O legado contratualista nas teorias de RI}

Após uma breve exploração de como os cinco pensadores em questão abordam o contratualismo, busca-se, agora, analisar como algumas de suas ideias acabam contribuindo para o desenvolvimento ontológico e epistemológico de RI, especialmente para a formação do seu mainstream teórico. Hobbes (2005) é a maior referência, em se tratando de teoria política moderna, para a vertente realista de RI (Boisen; Boucher, 2010, p. 82), que, não por acaso, é a principal vertente dentre as teorias internacionalistas.

De antemão, frisa-se que a busca explicativa das relações internacionais atuais à luz de autores de épocas tão distantes exige uma análise contextualizada, para se esvair de anacronismos. Vislumbram-se duas maneiras de se interpretar a ordem internacional a partir das (im)possibilidades políticas vislumbradas pelos contratualistas, quais sejam: aplicar o que eles afirmam explicitamente sobre a ordem internacional de seu tempo, que, em verdade, é pouco ${ }^{17}$; ou testar a validade atual do que está implícito sobre o cenário internacional da Idade Moderna. Optamos pela segunda.

A ideia de que o Estado age de forma racional para sobreviver antropomorfizando-o e dando sua raison d'être - pode ser considerada como um dos principais legados que a comunidade epistêmica de RI extrai dos contratualistas, seja para ser validada, seja para ser refutada por outras correntes. Mas, como já apontado, os contratualistas não são coincidentes em suas propostas, fazendo surgir as mais variadas vertentes teóricas em RI.

Grosso modo, o desenvolvimento das teorias de RI ocorre no alvorecer do

\footnotetext{
${ }^{17}$ Sobre tal assunto aplicado ao caso hobbesiano, ver Walker (2010, p. 170).
} 
século passado, quando os primeiros pensadores do liberalismo internacionalista sobretudo juristas, políticos e diplomatas como os Nobel da Paz Norman Angell e Woodrow Wilson - levam propostas deontológicas à então ordem internacional. Insatisfeitos com o alcance explicativo delas, adeptos do realismo político, como Edward Carr e Hans Morgenthau, respondem às tentativas normativas liberais, sobretudo no que tange à imprevisibilidade da Segunda Guerra Mundial. Os racionalistas Martin Wight e Hedley Bull, da chamada Escola Inglesa de RI, também contribuem significativamente por meio de seus estudos sobre o poder na política internacional, utilizando pressupostos tanto liberais quanto realistas.

Configura-se, assim, o apogeu do primeiro grande debate teórico de RI. Se, por um lado, com a criação das Nações Unidas, os ideais liberais se renovam; por outro, a configuração da Guerra Fria fornece mais combustível para realistas aperfeiçoarem sua ideia-força de anarquia internacional, com especial atenção para Kenneth Waltz e sua teoria sistêmica das relações internacionais. Nesse ínterim, a corrente pluralista nasce do pensamento liberal que vê na interdependência complexa entre as nações uma forma de superar a anarquia internacional, sendo tal concepção aperfeiçoada e reformulada por Joseph Nye e Robert Keohane, passando a se chamar neoliberalismo, a qual apregoa a convivência de organismos e regimes internacionais em um mundo ainda anárquico e centrado no Estado. Assim, emerge o debate neo-neo, colocando lado a lado neorrealismo e neoliberalismo ${ }^{18}$. Com a queda do Muro de Berlim, novos debates teóricos e correntes de pensamento - especialmente o construtivismo e a Escola de Copenhague - surgem e estão em constante desenvolvimento.

O mais interessante da construção de todo esse arcabouço teórico - e, portanto, o que diferencia epistemologicamente RI de outros campos científico, na acepção bourdieusiana - é que seus conceitos e pressupostos mais básicos podem ser remontados, de alguma forma, aos contratualistas. Dito de maneira diferente, a forma com que as mais diversas tentativas de analisar e explicar como o mundo realmente é ou deveria ser baseiam-se, muitas vezes, em um dos aspectos apresentados no

\footnotetext{
${ }^{18}$ Algumas teorias de RI sofrem de imprecisão terminológica. Por exemplo, Castro $(2016$, p. 340) apregoa que, nos estudos internacionalistas, "o liberalismo [...] assume diferentes facetas de nomenclatura". Eis algumas: idealismo (Castro, 2016, p. 46, 340; Silva; Gonçalves, 2010, passim), liberalismo utópico (Jackson; Sørensen, 2007, passim) e liberalismo idealista (Castro, 2016, p. 326). Atenta-se para o uso pejorativo dado ao liberalismo, que se deve ao realista Carr (2001, p. 10-14, 21). Já o neorrealismo pode ainda ser referendado por realismo estrutural, com as vertentes realismo ofensivo e defensivo. E o neoliberalismo pode vir grafado como liberalismo institucional, liberalismo institucionalista ou institucional liberalismo.
} 
esquema pseudotripartite da Figura 1 e nos conceitos identificados na terceira seção. É essa relação entre contratualismo e teorias de RI que as próximas três subseções pretendem desvendar.

\subsection{O legado do Estado de Natureza para as teorias de RI}

O mainstream teórico de RI concebe o estado de natureza como um modelo universal da dinâmica internacional, de forma a revelar a existência da chamada anarquia internacional, que parece ser o principal corolário das teorias internacionalistas.

A anarquia internacional é tanto "uma multiplicidade de potências sem governo" quanto uma "característica que distingue a política internacional da política ordinária" (Wight, 2002, p. 92-93). Ela se origina no fato de não existir um ente regulador acima de todos os Estados - ou, em outras palavras, de inexistir um Leviatã para gerir a ordem internacional e engendrar normas vinculantes -, igualmente como geralmente se observa no estado de natureza, ou, em outros termos, como se vê internamente no estado civil.

Sob a argumentação hobbesiana de que há uma predisposição natural do homem para o conflito - i.e., o estado de natureza coincide com o estado de guerra -, os realistas clássicos apregoam que a guerra é a principal fomentadora das relações internacionais, consoante (re)leituras, dentre outros, de Tucídides (2001) acerca da Guerra do Peloponeso, há 2.500 anos.

A seara internacional caracteriza-se, portanto, por ser um pluriverso em que as unidades políticas buscam manter sua integridade jurídica e ser reconhecidas perante outras potências (Schmitt, 1984). Logo, a iminência da guerra pela sobrevivência (SaintPierre, 2011, p. 424) leva a uma semelhança com o estado de natureza proposto por Hobbes. Contudo, uma das principais rejeições ao realismo se refere justamente ao emprego desse conceito enviesado nas relações internacionais. Veja-se, por exemplo, Bull (2002, p. 58-59), para quem o argumento de que o sistema internacional moderno se assemelha ao estado de natureza hobbesiano pode ser considerado fraco porque "a ausência de um governo universal não se tem mostrado incompatível com a 
interdependência econômica das nações", cenário melhor visto no século XX. Contudo, sobre o estado de guerra, Bull (1981, p. 721; 2002, p. 59) informa, ainda, que esse sim pode ser aplicado às relações internacionais, já que isso não quer dizer que exista confronto entre os atores, mas, sim, que eles estão em prontidão para fazê-lo. Como se vê, a acepção de anarquia realista é mantida por teóricos internacionalistas, no sentido de concebê-la, ao mesmo tempo, como cenário estratégico e causadora de conflitos internacionais (Wight, 2002, p. 93).

Como se percebe, Hobbes (2005) versa muito sobre a guerra, a ponto de Barnabé (2012, p. 55) observar que os Estados, assim como os indivíduos, agem orientados com base na autopreservação e na precaução/desconfiança, acrescentando que os indivíduos buscam naturalmente acumular cada vez mais poder. Essa propensão humana à guerra - como se vê no Quadro 1, no que se refere ao estado de natureza hobbesiano - faz com que os Estados sejam levados a uma preparação constante para a defesa de sua soberania (Miguel, 2010), de forma a diminuir, assim, a segurança geral - os realistas chamam isso de dilema de segurança.

A anarquia internacional é, pois, fruto da interpretação mais afamada de Hobbes (2005), a qual é decorrente da comparação das capacidades entre Estados e indivíduos - no estado de natureza - com seus iguais. Mais precisamente, tal tema diz respeito aos monarcas que reagem a seus semelhantes vizinhos em um estado de guerra (Bull, 1981, p. 720-721). Com base em Bull (1981), esse estado de coisas não necessariamente resulta em um sistema de atores marcados pelo egoísmo alheio, de modo que os Estados ainda podem cooperar. Vale lembrar que o estado de guerra entre os soberanos não implica necessariamente uma condição degradante de seus súditos - como no estado de natureza - e que os homens podem fazer com que ideais de paz cheguem à Lei Maior de cada Estado (Bull, 1981, p. 727-729). Essa última assertiva encontra mais ressonância no contratualismo kantiano.

Kant (2008, p. 15), como visto na terceira seção, apregoa que o estado de natureza se caracteriza pela falta de leis externas ao Estado. Nesse viés, pode-se dizer que, para ele, o sistema internacional está mais propenso para um estado de natureza internacional do que um civil, haja vista que, mesmo com os Estados já tendo, logicamente, saído do estado de natureza, o sistema internacional continua sem possuir leis erga omnes. A junção das ideias propostas por Hobbes (2005) e Kant (2008) pode ser vista na afirmação de que "[o] sistema internacional de Estados é 
caracterizado pela ausência de uma autoridade central capaz de impor e fazer valer regras e leis internacionais de caráter global" (Silva; Gonçalves, 2010, p. 50). Assim, lei natural e lei das nações estão associadas, "pois aquilo que é a lei da natureza entre indivíduos e indivíduo antes da constituição da comunidade é a lei das nações, posteriormente, entre soberano e soberano" (Hobbes, 2005, p. 197). Essa relação destaca a originalidade do pensamento hobbesiano ao observar que as relações internacionais operam em um vácuo moral (Boisen; Boucher, 2010, p. 90), tão temido por Kant (2008) e tão negado por Rousseau (Waltz, 2004, p. 213).

Ainda acerca da natureza humana, Walker (2010, p. 177) afirma que a preocupação central na formulação de teorias internacionalistas deveria ser a distinção das ordens externas e internas, e não a busca por compreensões psicológicas. Apesar da crítica, ocorre que, para ele, Hobbes é bem-sucedido na transposição de características daquela natureza, do âmbito interno (sua principal fonte de preocupação) para o externo (uma preocupação marginal em suas formulações), tornando-se, por conseguinte, uma fonte rica para teóricos, inclusive de RI.

Para o neorrealista Waltz (2004), o pensamento espinosista se direciona à linha tida como "pessimista" da natureza humana em RI e encontra ressonância principalmente com o realista clássico Morgenthau. Embora os escritos de Espinosa e Morgenthau confluem no sentido de que a vida em sociedade precisa ser regulada, ambos divergem sobre o que gera os males políticos e sociais - que, no plano internacional, podem acarretar guerras -: para o primeiro, é o embate entre razão e paixão; e, para o segundo, é o próprio homem, por ser completamente falho (Waltz, 2004). Tendo o fator psicológico como principal guia para explicar o comportamento humano, Espinosa (2008) enfatiza que o ser humano é regido pelo desejo de autopreservação. Levando em conta tal aspecto, Waltz (2004) pondera que, na perspectiva espinosista, o princípio de autopreservação encontraria mais espaço na ideia de que "todo homem busca de fato promover seus próprios interesses, mas, por infelicidade, não de acordo com os ditames da razão" (Waltz, 2004, p. 31-32) ${ }^{19}$. A importante obra Teoria da Política Internacional, de Waltz (1979), enfatiza os

\footnotetext{
${ }^{19}$ As proposições contratualistas de Espinosa (2008) e Rousseau (2003) são tratadas de forma divergente em Waltz (2004), estando o pensamento espinosista muito mais atrelado à questão do sistema de Estados do que à natureza humana, e tendo, por conseguinte, forte impacto em Waltz (1979).
} 
constrangimentos provocados pela configuração inerente à estrutura internacional que determinam a própria condução das relações internacionais ${ }^{20}$. A ligação entre o neorrealismo waltziano e o estado de natureza hobbesiano é explicitada pela irreversível ausência de uma autoridade superior internacional (Rosas, 2009, p. 9).

Estabelecer um paralelo entre o pensamento contratualista lockiano e o da teoria neoliberal de RI também se mostra imprescindível ao objetivo deste artigo. A partir dos anos 1970 e do surgimento do paradigma pluralista, o neoliberalismo acaba por enfatizar o papel de novos atores - sobretudo, dos não estatais, como empresas multinacionais e organizações internacionais - na política internacional, mesmo diante da anarquia internacional, transformando-se em um contraponto ao realismo e à sua visão westfaliana da política internacional. É importante frisar que neoliberais tendem a notar certa semelhança entre o sistema internacional e o estado de natureza lockiano (Rosas, 2009, p. 12-13).

Para Locke, as relações internacionais dão-se de forma análoga às encontradas no estado de natureza, e, nesse caso, "a cooperação seria a norma[;] e a guerra[,] a exceção, pois [...] a guerra não é uma propensão natural do ser humano, mas é a resultante do mau funcionamento das instituições" (Mapa, 2011). Depreende-se da lógica lockiana que os Estados são atores movidos pela razão, assim como os indivíduos. É essa racionalidade estatal que permite que os Estados ajam de maneira cooperativa, pois eles buscam minimizar suas perdas, criando uma harmonia de interesses no sistema internacional. Esse pressuposto se aproxima, igualmente, do estado de natureza kantiano e rousseauniano, apesar de ser mais um traço comum da "escola liberal de RI" do que um tema explicitamente abordado em suas respectivas obras. Tais caracteres normativos, juntamente com seus desdobramentos teóricos, são fortemente criticados pelo realista clássico Carr (2001), que, ainda nos anos 1940, destina aos liberais clássicos o epíteto de "utópicos". Por fim, o legado rousseauniano para as RI, por sua vez, não está amarrado à comparação entre atores estatais no sistema internacional e indivíduos no estado de natureza, mas sim à interação entre sociedades e à propensão à cooperação.

\footnotetext{
${ }^{20}$ Um exemplo dessa máxima vem da Guerra Fria, quando EUA e União Soviética imitavam os passos um do outro: quando um deles criava uma organização internacional para assuntos de defesa, o outro replicava o modelo; quando um intentou criar um sistema de escudos antimísseis, o outro afirmou que faria o mesmo etc. Enfim, nesses casos, a estrutura do sistema internacional - anarquia e bipolaridade constrangia as ações de ambas as potências, as quais era levadas em conta pelas demais potências.
} 
Na visão realista, a afirmação de o sistema internacional ser anárquico é o que condiciona o comportamento dos Estados, assim como a ausência de um governo no estado de natureza é o que determina uma guerra de todos contra todos. Para Waltz e Hobbes, um indivíduo ou um Estado que tente ir contra tal situação acabará pagando o preço sozinho, pois não há como reverter essa realidade na ausência de uma autoridade superior. Já para os liberais - sobretudo os da vertente neo -, esse cenário pode ser minimizado por meio da cooperação internacional.

\subsection{O legado do Contrato Social em RI}

Praticamente, todo Estado soberano possui uma Carta Magna (sistema do civil law) ou um conjunto esparso de leis e de julgados (sistema do common law) que o funda e constitui. Vejamos isso aplicado à Constituição brasileira de 1988, que apresenta as seguintes passagens que podem ser relacionadas ao pensamento contratualista:

- o fato de o Brasil (1988, art. $1^{\circ}$, caput) constituir-se em Estado Democrático de Direito, de a soberania ser um fundamento desse Estado $^{21}$ (Brasil, 1988, art. $1^{\circ}, 1$ ), de a liberdade ser um substrato fundamental para se construir a sociedade brasileira (Brasil, 1988, art. $3^{\circ}$, I) e de a propriedade ser um direito garantido igualmente a todos (1988, art. $5^{\circ}$, caput);

- a constatação de que todo o poder emana do povo (Brasil, 1988, art. 1, parágrafo único); e

- o mais importante para o objetivo deste trabalho: fixar que o Brasil (1988, art. 4, I, III, IV, V, VI, VII, IX) rege-se em suas relações internacionais por princípios como independência nacional, autodeterminação dos povos, não-intervenção, igualdade entre os Estados, defesa da paz, solução pacífica dos conflitos e cooperação entre os povos para o progresso da humanidade.

\footnotetext{
${ }^{21}$ Pode-se ligar, é verdade, essa passagem constitucional à máxima bodiniana de que a soberania é "o fundamento principal de toda República" (Bodin, 2011, p. 197).
} 
Ora, se cada Estado é, do ponto de vista internacional, soberano e independente, então suas constituições e textos fundamentais seguem as convicções de sua própria sociedade. Isso faz surgir questões como: sendo os Estados soberanos, é possível fazer analogias acerca do contrato social no âmbito internacional? Como o mainstream teórico de RI se utiliza do legado contratualista para analisar a inexistência de um Leviatã internacional? Vejamos.

Para Hobbes (2005, cap. XVII, grifo do autor), o passo automaticamente seguinte ao contrato social é a criação do "Estado, [que] em latim [é] civitas. É esta a geração daquele grande Leviatã, ou antes [...] daquele Deus Mortal, ao qual devemos, abaixo do Deus Imortal, nossa paz e defesa". Ao contrário do que faz, por exemplo, Espinosa (2008), a maioria dos contratualistas afirma que, acima dos Estados, há somente uma entidade divina. O reflexo dessa constatação pode ser visto quando alguns Estados democráticos continuam a proclamar uma autoridade celestial em seus motes, tais como "Deus salve a Rainha", "Deus abençoe a América" e "Em Deus nós confiamos". Nesse viés contratualista, se o Estado está acima dos súditos/cidadãos e abaixo de Deus, então nenhuma instituição artificial pode ordenar as relações internacionais? Para Walker (2010, p. 178), o problema de se fazer analogias como a da frase anterior é que elas geralmente não consideram a diferença entre indivíduos e Estados, que, sob um viés contratualista, são atores terminantemente diferentes, seja em status legal - que, na linguagem atual, implica no problema da soberania -, seja de escala micro-macro, seja de (i)mortalidade do Estado 22 .

A aplicabilidade do pensamento de Hobbes às relações internacionais também se revela quando ele trata da sobrevivência do Estado em um ambiente destituído de um Leviatã supranacional. Nesse caminho, Barnabé (2012, p. 59) comenta: “[a]ções que, dentro da sociedade civil, poderiam ser qualificadas de ilegais, injustas ou imorais, podem ser amplamente realizadas pelo governante sob a justificativa da preservação do Estado".

A releitura de Hobbes (2005) concentra-se na luta e na busca incessante do poder, bem como na vontade de acumulá-lo - expressada no momento do firmamento do contrato social. Ela está, como já dito, assentada na natureza humana, de onde se alinha o pensamento realista. De acordo com Bull (1981, p. 717), Morgenthau sistematiza com êxito as premissas do realismo internacionalista, dentro do que se

\footnotetext{
${ }^{22}$ Sobre este último aspecto, cf. Bodin (2011, p. 197) e Bull (1981, p. 734).
} 
entende por "tradição hobbesiana", embora sua base argumentativa, seu contexto histórico e seu método de análise sejam diferentes dos do seiscentista inglês. Pode-se constatar que implicações de perspectiva hobbesiana ressoam nos dois primeiros princípios do realismo clássico propostos por Morgenthau, quando este apregoa que a política e a sociedade em geral são "governada[s] por leis objetivas que deitam suas raízes na natureza humana" (Morgenthau, 2003, p. 4), colocando a racionalização do interesse em política externa em termos de poder (Morgenthau, 2003, p. 7).

Ao construir as bases do individualismo liberal, Locke influencia pensadores iluministas. Além disso, suas ideias são fundamentais para a consecução da Revolução Americana, quando a Declaração de Independência - o grande contrato social, por assim dizer - "foi redigida e a guerra de libertação foi travada em termos naturais e de direito de resistência para fundamentar a ruptura com o sistema colonial britânico" (Mello, 1999, p. 89). Isso tudo sem falar na contribuição lockiana para a consolidação da monarquia parlamentar em sua terra-natal.

Rousseau (2003) vê como descartável a perspectiva de que a irracionalidade humana é a causadora de todas as querelas, divergindo, portanto, de Espinosa (2008). De acordo com Waltz (2004, p. 213), embora esses dois contratualistas concordem que, no estado de natureza, prevaleçam os instintos e "impulsos físicos" dos homens, este difere daquele por reconhecer que, quando do contrato social, os homens substituem o instinto pela justiça em suas condutas.

Ao analisar o pensamento de Espinosa, Hobbes, Kant, Locke e Rousseau com suas respectivas concepções ontológicas centradas na razão, na paz, no Estado, no liberalismo e na democracia, findam por distinguir ator e sistema, bem como agente e estrutura, no quadro pós-contrato. Essas são importantes diretrizes utilizadas ainda hoje nas análises de política internacional. Para se ter ideia disso, Espinosa insere o direito natural da vida e a ação de indivíduos em seu direito natural, reafirmando-o em um contrato, pela formação de uma estrutura de princípios próprios. Mas as relações assimétricas de poder são consideradas distorções, visto que a capacidade de conformação do sistema de governo reside, em última instância, no povo (Chauí, 1995, p. 77). Aqui, o poder soberano é, por definição, a comunhão total da sociedade (Espinosa, 2008, p. 239), sendo a determinante do sistema de governo, embora um 
regime tirânico possa estar em vigência, tornando tal sistema uma variável relevante para os estudos, por exemplo, da Política Internacional Comparada, no âmbito de RI, e da qualidade democrática, no de CP.

\subsection{O legado do Estado Civil para teorizar RI}

Talvez, a analogia contratualista mais complexa de se operacionalizar em RI seja a do Estado Civil ${ }^{23}$ aplicado às relações internacionais. Seria possível um Estado Civil internacional, cujos moldes de fraternidade se aproximem mais da concepção kantiana? Ou, ao contrário, a falta de um Leviatã internacional, como defendem os (neo)realistas ${ }^{24}$, é o que eternamente configuraria a política internacional? Muito do que as teorias de RI buscam explicar parte dessas inquirições.

A contribuição rousseauniana para o entendimento de Waltz (1979) sobre a estrutura e a anarquia internacional consiste exatamente na visão do Estado enquanto ator unitário, premissa importante nas formulações das vertentes realista e neorrealista de RI. Nesse sentido, a análise de Rousseau (2003) exacerba a percepção do princípio neorrealista de que a explicação para a recorrência da guerra não se encontra na estrutura dos Estados per se, mas, sim, na do sistema internacional, que acaba enredando as unidades em um contexto de autoajuda (Waltz, 1979), muitas vezes, de forma forçosa.

Aqui, uma atenção deve ser dada ao fato de que Hobbes (2005) não conjectura sobre um sistema de soberanos - correspondente mais próximo do que seria o sistema internacional atual -, uma vez que o mero agregado de unidades e de suas vontades não constitui necessariamente um sistema (Walker, 2010, p. 174).

No que diz respeito a Locke, seu pensamento influencia a política internacional e a filosofia política contemporâneas. Por exemplo, Bobbio (1984, p. 41) afirma que, "através dos princípios de um direito natural preexistente ao Estado, de um Estado baseado no consenso, de subordinação do Poder Executivo ao Legislativo, de um poder limitado, de um direito de resistência, Locke expôs as diretrizes do Estado liberal".

\footnotetext{
${ }^{23} \mathrm{E}$, como um silogismo do esquema pseudotripartite, a ideia de Contrato Social também se mostra complicada em sua aplicação as relações internacionais.

${ }^{24}$ Um exemplo dessa assertiva pode ser vislumbrado no fato de a primeira linha do primeiro capítulo do livro dos neorrealistas Art e Waltz (1993, p. 1) caracterizar as relações internacionais como sendo governada pela anarquia internacional, grande fomentadora do recurso ao uso da força entre os Estados.
} 
Outro exemplo lockiano pode ser visto no liberalismo político que impregna os discursos e as ações de alguns chefes de Estado no início do século XX, sobretudo de ex-presidente estadunidense Woodrow Wilson, cujas bases estão fincadas tanto em liberais clássicos como Norman Angell quanto nos contratualistas Kant, Locke e Rousseau. Este último, por seu turno, ao depositar fé na opinião pública - como um corolário da liberdade de expressão (Rousseau, 2003, p. 144), algo que, certamente, va ao encontro tocquevilliano -, acaba por sintetizar máximas liberais muito presentes até mesmo no início do século passado, quando, por exemplo, os EUA entraram na Segunda Guerra Mundial, após a repercussão nacional dos ataques a Pearl Harbor com o intuito de "libertar" o mundo da tirania nazista, ou, mesmo, no século XXI, ao retomar uma versão repaginada do fardo do homem branco, ao buscar levar a democracia ao "mundo livre".

Outro assunto que ganha relevo nas teorias de $\mathrm{RI}$ - e que diz respeito a um Estado Civil internacional - é a possibilidade de existir uma sociedade de Estados ou sociedade internacional. Mas tal concepção não pode ser confundida com sistema internacional, já que é justamente nessa diferenciação que a teoria de RI inova, ao produzir um de seus maiores corolários: o conceito de sociedade anárquica.

Direcionado por uma lógica grotiana e rousseauniana, Bull (2002, p. 15-23) diferencia sociedade internacional de sistema internacional, no sentido de que a primeira constitui um grupo de Estados que, conscientes de certos valores e interesses comuns, relacionam-se via regras e instituições comuns (Bull, 2002, p. 19). Já o sistema internacional se perfaz "quando dois ou mais Estados têm suficiente contato entre si, com suficiente impacto recíproco nas suas decisões, de tal forma que se conduzam, pelo menos até certo ponto, como partes de um todo" (Bull, 2002, p. 15). Logo, uma sociedade internacional pode ser também um sistema internacional, mas é raro encontrar um exemplo o contrário. Isso é visto, por exemplo, na relação meramente comercial e voltada à guerra que os Estados europeus mantinham com os asiáticos, nos séculos XVI e XIX, em que tal situação representava um sistema internacional, porém os últimos não faziam parte da sociedade internacional centrada na Europa.

O contratualista que, versando sobre o Estado Civil, aproxima-se especificamente mais da formação de uma sociedade internacional, é Rousseau, cujas 
palavras parecem ecoar em Bull (2002), ao afirmar que:

é possível organizar outras [espécies de confederações], menos visíveis[,] mas igualmente reais, cimentadas silenciosamente pelos interesses compartilhados, os mesmos hábitos e costumes, a aceitação de princípios comuns e outros laços que criam relações mútuas entre nações politicamente divididas. Assim, as potências da Europa formam uma espécie de conjunto unido pela identidade de religião, moral e direito internacional; pelas letras, pelo comércio, e finalmente por uma espécie de equilíbrio que resulta inevitavelmente de todos esses vínculos (Rousseau, 2003, p. 73, grifo nosso).

Os termos "sociedade" e "anárquica" parecem gerar, à primeira vista, contradições por dois grandes motivos. Em primeiro lugar, "sociedade" pressupõe certo grau de afinidade e aproximação. Em segundo, "anárquica" dá a ideia de que existe uma situação de caos ou de falta de organização. A anarquia contida na definição de Bull (2002, p. 57-62) associa-se, como já mencionado repetidamente nesta seção, à ausência de um Leviatã mundial. Para Bull (2002, p. 62), a crítica de que o conceito de anarquia internacional, por se basear no estado de natureza hobbesiano, seja um argumento fraco é insuficiente, pois "a analogia do meio internacional com a ordem doméstica não passa de uma analogia, e o fato de que os [E]stados formam uma sociedade sem governo reflete características da sua condição que são únicas". Assim também reafirma Gonçalves, atrelando o conceito clássico weberiano ao de anarquia internacional:

\footnotetext{
É uma sociedade anárquica porque, embora não disponha de um poder central que detenha o monopólio da violência legítima, ela tem por característica um consenso entre os Estados que a compõem, em torno de alguns interesses comuns que procuram preservar mediante o respeito a determinadas instituições e normas (Gonçalves, 2002, p. XXV).
}

Todavia, os realistas tendem a discordar quanto à formação de uma sociedade internacional, pelo fato, dentre outros, de a analogia com o Estado Civil contratualista não se aplicar à realidade internacional. É o que apregoa Carr (2001, p. 93), ao afirmar que "qualquer tipo de sociedade internacional [é] impossível".

No que tange ao vocabulário próprio de RI, vê-se que alguns contratualistas buscam definir conceitos que são bastante utilizados até hoje nas análises internacionais e nos estudos internacionalistas. Por exemplo, Espinosa (2008, p. 243244) assevera que duas nações são aliadas quando, para evitar uma guerra, comprometem-se a não prejudicar e a se assistir quando necessário; já o inimigo pode ser tanto interno quanto externo, basta apenas que o indivíduo ou a nação não reconheça a autoridade de um Estado. De forma semelhante, Kant (2008, p. 28) e 
Rousseau (2003, p. 122) buscam precisar os termos Estado e potência, sendo o primeiro empregado quando se fala na atuação interna de um determinado povo; e o segundo, quando se versa sobre sua atuação externa, sobretudo no embate entre dois ou mais Estados. Cabe ressaltar, ainda, que, para Kant (2008, p. 5), o Estado não é uma propriedade, mas é, em verdade, a própria sociedade sobre a qual apenas o Estado pode governar. Já Rousseau (2003, p. 53, grifo nosso) chama de "guerra entre potências o resultado de uma disposição clara, constante e recíproca de destruir o Estado inimigo".

Finalmente, de acordo com Bull (2002, p. 34), Martin Wight, um dos expoentes da Escola Inglesa de RI, busca em Hobbes e Kant a gênese para explicar duas das três tradições do pensamento ocidental das quais originam as teorias de RI. Além da tradição racionalista, centrada em Hugo Grotius, há também a realista, de índole hobbesiana, que apregoa o cenário internacional como sendo aquele marcado pela constante competição e desconfiança dos Estados, em que a cooperação é até possível, mas geradora de ganhos relativos para as partes. E, em contrapartida, há a tradição revolucionária, inclinada às acepções kantianas de ganhos absolutos em caso de cooperação, princípio motivador dos revolucionários. A Figura 2 apresenta essas três tradições.

Figura 2 - As três tradições wightianas do pensamento ocidental nas teorias de RI

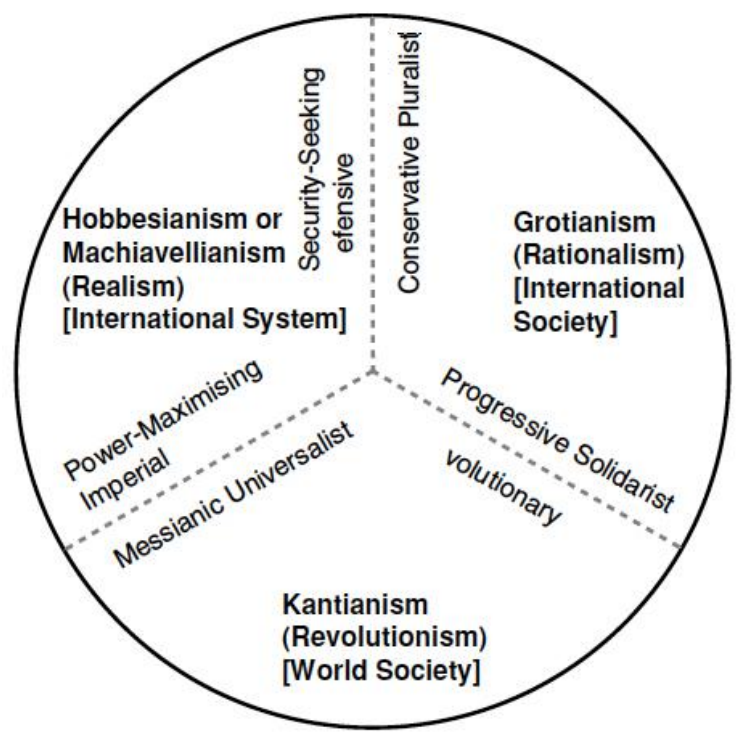

Fonte: Buzan, 2004, p. 9.

Como analisado nesta seção, o legado deixado pelos contratualistas encontra 
uma relação fortemente positiva em RI, especialmente no que tange a suas teorias, e, mais especificamente, ao mainstream internacionalista, qual seja, o realismo político. Nesse viés, pode-se dizer que a hipótese principal, apresentada na seção introdutória, não pode ser facilmente refutada, a partir da análise aqui realizada. Resta, portanto, saber se o objetivo geral deste trabalho foi alcançado, tarefa realizada na próxima seção.

\section{Considerações finais}

Validar questões contemporâneas com o auxílio de pressupostos que, embora antigos, permaneçam "clássicos" é uma metodologia analítica bastante empregada nas diversas ciências sociais, inclusive em CP e RI. Nesse sentido, o legado contratualista em RI pode ser resumidamente exposto a seguir.

Especificamente, quanto a Espinosa (2008), notam-se as seguintes rupturas, em relação aos demais contratualistas analisados: (i) alocação do fim último dos homens na manutenção de sua força de sobrevivência (conatus), e não na sobrevivência em si; e (ii) enquadramento do estado civil como continuidade lógica da convivência natural entre seres humanos. Ao contrário dos outros contratualistas, o legado espinosista não é muito consolidado nas teorias de RI, haja vista que um de seus conceitos mais importantes, o conatus, é praticamente desconhecido dos estudiosos da área, conforme se observa pelas duas últimas linhas da Tabela 1.

A concepção que Hobbes tem de nações não lhe permite vislumbrar uma ordem internacional como a que se delineia nos séculos seguintes - ao contrário, por exemplo, da tentativa normativa de Kant (Walker, 2010, p. 170). Entretanto, seus conceitos de anarquia e de estado de guerra permanecem como um dos principais corolários de RI. Além isso, Hobbes tem sido forçosamente enquadrado nas concepções realistas - e, em certos casos, Kant (2008) nas liberais. Porém, como destaca Walker (2010, p. 172), nenhum autor deve ser obrigado a tal posição, muito menos em uma categoria de realismo político que abrange todo um ramo privilegiado de RI.

Locke (2006), diferentemente de Hobbes, aponta para o estado de natureza com certo caráter otimista: os homens, acobertados pelas leis naturais, têm suas vida, liberdade e propriedade asseguradas, de forma a prevalecer a cooperação.

Já Rousseau (2003) traz a noção de cooperação para as relações internacionais, 
que, aliada à busca pela paz kantiana, por meio de uma confederação de Estados fraternos, são os motes utilizados pela vertente liberal de RI para fazer frente à leitura realista de Hobbes. Em termos rousseaunianos, diz-se que, no sistema internacional, os Estados ainda não firmaram uma espécie de "Contrato Social Internacional", fazendo com que eles convivam, mas não vivam entre si, fundamentando, assim, o princípio jurídico-internacional da suportabilidade entre os Estados. Assimilando - em doses bem diferentes, é verdade - Kant, Locke e Rousseau às suas teorias, a vertente liberal de RI busca levar tal conceito de suportabilidade às relações internacionais, quase com sinônimo de fraternidade, por meio da convivência entre atores estatais e não estatais, envoltos pelos regimes internacionais.

Os teóricos contratualistas, ao se preocuparem com a sistematização lógica e subjetivação do estudo clássico da política, certamente se tornam referências fundamentais para os estudos políticos, internacionais e internacionalistas atuais, ainda que, contra seus métodos e modelos, pesem críticas. Assim, RI está suscetível de encontrar amplas aplicações, bem como discordâncias frequentes, ao buscar respostas teóricas na Modernidade. Isso se deve, dentre outros motivos, ao próprio caráter generalista das ciências sociais na atualidade (King, Keohane e Verba, 1996, p. 1-12) e ao fato de que os contratualistas não concordam plenamente entre si sobre a "vida e morte" do Estado, sobretudo no plano internacional.

Este trabalho resume os principais conceitos-chave de contratualistas da política moderna às teorias de $\mathrm{Rl}$, especialmente a seu mainstream. Por fim, a título exemplificativo, frisa-se que a falta de consenso entre os contratualistas - daí a existência das várias vertentes e teorias internacionalistas que, em termos bourdieusianos, lutam nesse campo científico - destaca sua diversidade de pensamento. Em outras palavras, esta análise buscou apontar como o legado contratualista mantém-se vivo e resiliente nas teorias de RI até hoje. 


\section{Referências bibliográficas}

ART, R. J.; Waltz, K. N. 1993. The use of force: military power and international politics. 4. ed. Lanham: University Press of America.

AURÉliO, D. P. 2008. "Notas". In: Espinosa, B. de. Tratado teológico-político. São Paulo: Martins Fontes.

BARNABÉ, G. 2009. "As Relações Internacionais no pensamento de Thomas Hobbes". Philósophos, Goiânia, v. 14, n. 1, p. 45-77.

CERVO, A. L.; Bervian, P. A.; Da Silva, R. 2010. Metodologia científica. 6. ed. 5. reimp. São Paulo: Pearson Prentice Hall.

BOBBIO, N. 1984. Direito e Estado no pensamento de Emanuel Kant. Brasília: Ed. UnB.

BOBBIO, N. Matteucci, N.; Pasquino, G. 2004. Dicionário de Política. Brasília: Ed. UnB.

BODIN, Jean. 2011. Os seis livros da República. Tradução: José Carlos O. Morel. São Paulo: Ícone, v. 1. (Fundamentos do direito).

BOISEN, C.; Boucher, D. 2010. "Hobbes and the subjection of International Relations to Law and morality". In: Prokhovnik, R.; Slomp, G. (Orgs.). International Political Theory after Hobbes: analysis, interpretation and orientation. Basingstoke: Palgrave Macmillan.

BONAVIDES, P. 2006. Ciência Política. 13. ed. São Paulo: Malheiros, 2006.

BRADY, H.; Collier, D.; Seawright, J. 2004. "Refocusing the discussion of methodology". In: Brady, H.; Collier, D. (Eds.). Rethinking social inquiry: diverse tools, shared standards. New York: Rowman \& Littlefield Publishers. cap. 1, pp. 3-20.

BRASIL. 1988. Constituição Federal. Brasília: Presidência da República. Disponível em: <http://www.planalto.gov.br/ccivil_03/Constituicao/ConstituicaoCompilado.htm>. Acesso em: 7 jan. 2016.

BULL, H. 1981. "Hobbes and the International Anarchy". Social Research, v. 48, n. 4, pp. 717738.

BULL, H. 2002. A sociedade anárquica: um estudo da ordem na política mundial. Tradução: Sergio Bath. Brasília e São Paulo: Ed. UnB/IPRI/IOESP.

BUZAN, B. 2004. From international to world society? English School theory and the social structure of globalisation. Cambridge, UK: Cambridge University Press.

CARR, E. H. 2001. Vinte anos de crise 1919-1939. Brasília: Ed. UnB.

CASTAN, Y. 1991. "Política e vida privada". In: Ariès, Philippe; Duby, Georges (Orgs.). História da vida privada: da Renascença ao Século das Luzes. São Paulo: Companhia das Letras, v. 3, pp. 27-69.

CASTRO, T. 2016. Teoria das relações internacionais. 2. ed. Brasília: FUNAG. 
CHAUÍ, M. 1995. Espinosa: uma filosofia da liberdade. São Paulo: Moderna.

ESPINOSA, B. de. 2008. Tratado teológico-político. Trad. Diogo P. Aurélio. São Paulo: Martins Fontes.

HARDIN, R. 2007. "Compliance, consent, and legitimacy". In: Boix, Carles; Stokes, Susan C. (Eds.). The Oxford handbook of Comparative Politics. Oxford: OUP. cap. 10. pp. 236-255.

HOBBES, T. 2005. Leviatã. São Paulo: Rideel.

JACKSON, R.; Sørensen, G. 2007. Introdução às Relações Internacionais: teorias e abordagens. Trad. Bárbara Duarte. Rio de Janeiro: Jorge Zahar.

KANT, I. 2008. A paz perpétua: um projecto filosófico. Trad. Artur Morão. Covilhã: Lusofonia Press.

KING, G.; Keohane, R.; Verba, S. 1994. Designing Social Inquiry. New Jersey: Princeton University Press.

LOCKE, J. 2006. Segundo tratado sobre o governo civil e outros escritos. Rio de Janeiro: Ed. Vozes.

MAPA, D. 2011. "Filosofia política e relações internacionais: considerações sobre a pluralidade epistemológica da disciplina". In: $3^{\circ}$ Encontro Nacional da ABRI, São Paulo, Proceedings. Disponível em: <http://www.proceedings.scielo.br/pdf/enabri/n3v1/a64.pdf>. Acesso em 22 dez. 2014.

MELLO, L. 1999. "John Locke e o individualismo liberal". In: Weffort, F. C. Os clássicos da política. São Paulo: Ática, v. 1.

MIGUEL, V. 2010. A perspectiva realista na teoria das relações internacionais. Disponível em: $<$ http://jus.com.br/artigos/17929/a-perspectiva-realista-na-teoria-das-relacoes-

internacionais>. Acesso em 22 dez. 2014.

MORGENTHAU, H. 2003. A Política entre as nações: a luta pelo poder e pela paz. Brasília: Ed. UnB.

ROSAS, G. 2009. "Hobbes versus Locke: a contribuição do estado de natureza para as perspectivas realista e pluralista das Relações Internacionais". e-Civitas, v. 2, n. 1, p. 1-16.

ROUSSEAU, J. 2003. Rousseau e as Relações Internacionais. São Paulo: FUNAG/IPRI/UnB/IOESP.

SAINT-PIERRE, H. L. 2011. "'Defesa' ou 'Segurança'? Reflexões em torno de conceitos e ideologias". Contexto int., Rio de Janeiro, v. 33, n. 2, dez. 2011. Disponível em: <http://dx.doi.org/10.1590/S0102-85292011000200006>. Acesso em 18 jan. 2015.

SCHMITT, C. 1984. El concepto de lo "político". Buenos Aires: Folios Ediciones.

SILVA, G. A.; GONÇALVES, W. 2010. Dicionário de Relações Internacionais. 2. ed. Barueri: Manole. 
TUCíDIDES. 2001. A Guerra do Peloponeso. 4. ed. Brasília e São Paulo: Editora UnB/IPRI/IOESP.

WALKER, R. B. J. 2010. "Hobbes, Origins, Limits". In: Prokhovnik, R; Slomp, G. (Eds). International political theory after Hobbes: analysis, interpretation and orientation. Palgrave Macmillan: Basingstoke; New York.

WALTZ, K. 1979. Theory of international politics. Nova lorque: McGraw-Hill.

WALTZ, K. 2004. O homem, o Estado e a guerra: uma análise teórica. São Paulo: Martins Fontes.

Revisado por Barbara Soares

Tramitação do artigo na revista Submetido: 25/02/2015

Revisões requeridas: 30/11/2015

Versão revista: 15/01/2016

Aceito: 5/11/2017 